\title{
TAX AVOIDANCE DITINJAU DARI CORPORATE GOVERNANCE PADA PERUSAHAAN PROPERTY DAN REAL ESTATE
}

\author{
Ema Murtia Ningrum \\ Email: emamurtianingrum11@gmail.com
}

Fakultas Ekonomi, Program Studi Akuntansi, Universitas Islam Batik Surakarta

J1. Agus Salim No.10, Sondakan, Kec. Laweyan, Kota Surakarta, Jawa Tengah 57147

Yuli Chomsatu Samrotun

Email: chom_satoe@gmail.com

Fakultas Ekonomi, Program Studi Akuntansi, Universitas Islam Batik Surakarta

Jl. Agus Salim No.10, Sondakan, Kec. Laweyan, Kota Surakarta, Jawa Tengah 57147

\author{
Rosa Nikmatul Fajri \\ Email: Rosanikmatulfajri@mail.ugm.ac.id \\ Fakultas Ekonomi, Program Studi Akuntansi, Universitas Islam Batik Surakarta \\ J1. Agus Salim No.10, Sondakan, Kec. Laweyan, Kota Surakarta, Jawa Tengah 57147
}

\begin{abstract}
ABSTRAK
Tax Avoidance dilakukan oleh wajib pajak (perusahaan) untuk meminimalkan beban pajak perusahaan. Penelitian ini bertujuan untuk mengetahui dan menganalisis pengaruh corporate governance yang terdiri dari kepemilikan institusional, dewan komisaris, kualitas audit, dan komite audit terhadap tax avoidance. Populasi penelitian ini adalah 48 perusahaan Property dan Real Estate yang terdaftar di BEI tahun 2014 - 2018. Pengambilan sampel menggunakan teknik purposive sampling, perusahaan yang tepilih sebanyak 23 perusahaan. Teknik analisis data yang digunakan adalah regresi linier berganda. Hasil penelitian ini kepemilikan institusional, dewan komisaris, kualitas audit, dan komite audit berpengaruh secara simultan terhadap tax avoidance. Secara parsial, dewan komisaris dan kualitas audit berpengaruh negatif terhadap tax avoidance. Sedangkan kepemilikan institusional dan komite audit tidak berpengaruh terhadap tax avoidance. Manfaat dari penelitian ini adalah memberikan tambahan informasi bagi pengembangan ilmu pengetahuan di bidang akuntansi perpajakan.
\end{abstract}

Kata Kunci : Corporate Governance; Tax Avoidance.

\begin{abstract}
Tax Avoidance is carried out by taxpayers (companies) to minimize the corporate tax burden. This study aimed to determine and analyze the influence of corporate governance consisting of institutional ownership, the board of commissioners, audit quality, and audit committee on tax avoidance. The population of this research was 48 Property and Real Estate companies listed on the Indonesia Stock Exchange in 2014 - 2018. Sampling used a purposive sampling technique; 23 selected companies were selected. The data analysis technique used is multiple linear regression. The results of this study are institutional ownership, the board of commissioners, audit quality, and audit committee simultaneously influence tax avoidance. Partially, the board of commissioners and audit quality negatively affect tax avoidance, whereas institutional ownership and audit committees do not affect tax avoidance. The benefit of this research is to provide additional information for the development of science in tax accounting.
\end{abstract}

Keywords: Corporate Governance; Tax Avoidance. 


\section{PENDAHULUAN}

Anggaran pendapatan negara Indonesia tahun 2018 sebesar Rp 1.894,7 T, penyumbang utama pendapatan tersebut berasal dari sektor pajak sebesar Rp 1.618,1 T (Kementrian Keuangan, 2018). Pajak merupakan kontribusi wajib kepada negara yang terutang oleh orang pribadi atau badan sebagai wajib pajak dengan tidak mendapatkan timbal balik secara langsung, bersifat memaksa, dan pemungutannya dilakukan berdasarkan undang-undang (Darmawan \& Sukartha, 2014). Dalam upaya mengurangi beban pajak, agen dapat melakukan berbagai macam cara salah satunya penghindaran pajak. Penghindaran pajak (tax avoidance)merupakan suatu strategi pajak yang agresif yang dilakukan oleh perusahaan dalam rangka meminimalkan beban pajak. Sari (2014)menjelaskan bahwa tindakan tax avoidance dan masalah konflik agensi dapat diminimalisasi dengan corporate governance.Corporate Governance merupakan suatu keharusan dalam rangka membangun kondisi perusahaan yang tangguh dan sustainable serta sangat diperlukan untuk menciptakan sistem dan pengelolaan keuangan perusahaan yang kuatsehingga mampu menjadi perusahaan yang kompetitif (Darmawan \& Abdi, 2017). Corporate governance bertujuan agar terciptanya suatu tata kelola perusahan yang baik, efektif dan efisien. Corporate governance dalam penelitian initerdiri dari kepemilikan institusional, dewan komisaris, kualitas audit, dan komite audit.

Beberapa penelitian yang melatarbelakangi penelitian ini antara lain penelitian Jamei (2017) yang menyebutkan hasil bahwa kepemilikan institusional tidak berpengaruh terhadap penghindaran pajak. Namun hasil berbeda yang ditunjukkan oleh Mappadang, Widyastuti, \& Wijaya (2018) yang menyebutkan bahwa kepemilikan institusional berpengaruh terhadap penghindaran pajak. Penelitian yang dilakukan oleh Tandean \& Winnie (2016)menyebutkan hasil bahwa dewan komisaris tidak berpengaruh terhadap penghindaran pajak. Namun hasil berbeda yang ditunjukkan oleh Mappadang, Widyastuti, \& Wijaya (2018) menyebutkan bahwa dewan komisaris berpengaruh terhadap penghindaran pajak. Tandean \& Winnie (2016) menyebutkan hasil bahwa kualitas audit tidak berpengaruh terhadap penghindaran pajak. Namun hasil berbeda yang ditunjukkan oleh Mulyani et al. (2018) menyebutkan bahwa kualitas audit berpengaruh terhadap penghindaran pajak. Penelitian yang dilakukan oleh Puspita \& Harto (2014) menyebutkan hasil bahwa komite audit tidak berpengaruh terhadap 
penghindaran pajak. Namun hasil berbeda yang ditunjukkan oleh Mulyani et al. (2018) menyebutkan hasil bahwa komite audit berpengaruh terhadap penghindaran pajak.

Berdasarkan latar belakang masalah tersebut, maka rumusan masalah dalam penelitian ini antara lain (1) Apakah kepemilikan institusional berpengaruh terhadap tax avoidance? (2) Apakah dewan komisaris berpengaruh terhadap tax avoidance? (3) Apakah kualitas audit berpengaruh terhadap tax avoidance? (4) Apakah komite audit berpengaruh terhadap tax avoidance?. Tujuan dari penelitian ini yaitu untuk mengetahui dan menganalisis pengaruh kepemilikan institusional, dewan komisaris, kualitas audit, dan komite audit terhadap tax avoidance. Manfaat dari penelitian ini adalah (1) Manfaat Teoritis, dapat dijadikan referensi untuk penelitian selanjutnya pada waktu yang akan datang khususnya yang membahas tentang pengaruh kepemilikan institusional, dewan komisaris, kualitas audit, dan komite audit terhadap tax avoidance. (2) Manfaat Praktis, dapat dijadikan acuan dalam pengambilan kebijakan terkait penghindaran pajak, khususnya manajer.

\section{KAJIAN TEORI}

\section{Teori Keagenan (Agency Theory)}

Teori agensi menurut Jensen \& Meckling (1976)merupakan teori yang menjelaskan hubungan kontrak antara prinsipal (pemilik usaha) dan agen. Pemilik perusahaan atau pemilik saham perusahaan merupakan principal dan manajemen atau karyawan merupakan agent. Dalam penelitian ini digunakan teori keagenan untuk menjelaskan konflik antara pemegang saham atau pemilik perusahaan (principal) dengan manajemen (agent). Agency theory mengemukakan bahwa manajer akan bertindak oportunistik dengan mementingkan kepentingannya diri sendiri dibandingkan kepentingan pemegang saham. Manajemen melakukan tax avoidance untuk meningkatkan net profit after tax yang menyebabkan nilai perusahaan ikut meningkat. Dilain pihak, principal atau pemilik lebih menginginkan manajemen untuk lebih berhati-hati dalam menjalankan entitas dengan tidak melakukan tindakan penghindaran pajak yang akan berdampak pada reputasi perusahaan dan kelangsungan usahanya. Berdasarkan teori agensi, konsep corporate governance menjadi upaya dalam mengatur dan mengatasi perilaku manajemen yang mengutamakan kepentingan pribadi sehingga dapat terjadi keselarasan antara kepentingan pemegang saham dan manajer. 


\section{Tax Avoidance}

Menurut Pohan (2014), tax avoidance merupakan upaya penghindaran pajak yang dilakukan secara legal dan aman bagi wajib pajak tanpa bertentangan dengan ketentuan perpajakan yang berlaku dimana teknik dan metode yang digunakan cenderung memanfaatkan kelemahan - kelemahan yang terdapat dalam peraturan perpajakan. Tax avoidance diproksikan ke dalam Effective Tax Rates (ETR). "ETR adalah proksi yang paling banyak digunakan dalam penelitian terdahulu untuk mengetahui seberapa besar perusahaan melakukan tax avoidance" (Lanis \& Richardson, 2012). ETR adalah proksi negatif. Dimana jika ETR tinggi maka penghindaran pajak nya rendah, sedangkan bila ETR rendah maka penghindaran pajak nya tinggi.

ETR $=\frac{\text { Beban Penghasilan Pajak }}{\text { Pendapatan Sebelum Pajak }}$

\section{Corporate Governance}

Menurut(Haruman (2008), Corporate governance merupakan tata kelola perusahaan yang menjelaskan hubungan antara berbagai partisipan dalam perusahaan yang menentukan arah kinerja perusahaan. Corporate governance dalam penelitian ini meliputi kepemilikan institusional, dewan komisaris, kualitas audit dan komite audit. Masing-masing mekanisme tersebut dijelaskan sebagai berikut :

\section{Kepemilikan Institusional}

Menurut Susiana (2007)menyatakan bahwa persentase saham institusi adalah penjumlahan atas persentase saham perusahaan yang dimiliki oleh institusi atau lembaga baik yang berada di dalam atau di luar negeri. Perusahaan yang kepemilikan sahamnya lebih besar maka kinerja manajemen untuk dapat memperoleh laba yang diinginkan akan cenderung diawasi oleh investor institusi tersebut. Semakin besar kepemilikan institusional maka semakin kuat kendali yang dilakukan oleh pihak eksternal terhadap perusahaan. Ketika kepemilikan institusional menurun, maka tax avoidance akan mengalami kenaikian, dan sebaliknya. Kepemilikan Institusional dapat diukur dengan cara jumlah kepemilikan saham oleh investor institusi terhadap total jumlah sahamyang beredar (Annisa dan Kurniasih 2012).

$$
\mathrm{KI}=\frac{\text { Saham yang dimiliki institusional }}{\text { Jumlah saham yang beredar }}
$$




\section{Dewan Komisaris}

Kominte Nasional Kebijakan Governance (KNKG, 2006)mendefinisikan dewan komisaris sebagai mekanisme penggendalian internal tertinggi yang bertanggung jawab secara kolektif untuk melakukan pengawasan dan memberi masukan kepada direksi serta memastikan bahwa perusahaan melaksanakan Good Corporate Governance (GCG). Persentase dewan komisaris dalam suatu perusahaan secara tidak langsung mempengaruhi manajemen pajak. Perusahaan yang memiliki lebih banyak dewan komisaris maka akan lebih memiliki kesempatan menekan tingkat pajak dibandingkan perusahaan dengan perusahaan yang memiliki dewan komisaris yang lebih sedikit. Perhitungan Dewan Komisaris menggunakan jumlah anggota dewan komisaris dalam suatu perusahaan (Bukhori \& Raharja, 2012).

\section{Kualitas Audit}

Kualitas Audit adalah segala kemungkinan yang dapat terjadi saat auditor mengaudit laporan keuangan klien dan menemukan pelanggaran atau kesalahan yang terjadi, dan melaporkannya dalam laporan keuangan auditan.Dimensi kualitas auditor yang paling sering digunakan dalam penelitian adalah ukuran Kantor Akuntan Publik atau KAP. Menurut Guna \& Herawaty (2010), KAP Big Four dianggap lebih berkualitas karena dengan serangkaian pelatihan dan prosedur serta memiliki program audit yang dianggap lebih akurat dan efektif dibandingkan dengan KAP non Big Four. Penelitian ini menggunakan perusahaan yang diaudit oleh Kantor Akuntan Publik The Big Four yaitu Price Waterhouse Cooper-PWC, Deloitte Touche Tohmatsu, KPMG, Ernst dan Young- E dan Y akan diberi nilai 1, dan apabila tidak diaudit oleh KAP The Big Four akan diberi nilai O(Alviyani, Surya, \& Rofika, 2016).

\section{Komite Audit}

Berdasarkan Keputusan Bursa Efek Indonesia tentang Keputusan Direksi Bursa Efek Jakarta (BEJ) No.Kep-315/BEJ/06/2000 menyatakan bahwa komite audit adalah sebuah komite yang dibentuk oleh dewan komisaris perusahaan yang anggotanya diangkat dan diberhentikan oleh dewan komisaris. Komite bertugas membantu melakukan pemeriksaan yang dianggap perlu terhadap pelaksanaan fungsi direksi dalam pengelolaan suatu perusahaan. Winata (2014) menyatakan semakin banyak komite audit yang ada dalam suatu perusahaan dapat meminimalisir 
praktik tax avoidance yang dilakukan perusahaan. Perhitungan komite audit adalah jumlah total anggota komite dalam suatu perusahaan (Hanum \& Zulaikha, 2013).

\section{Penelitian Terdahulu}

Penelitian Marfirah \& Syam (2016) menunjukkan hasil bahwa kepemilikan institusional, dewan komisaris, kualitas audit, komite audit berpengaruh terhadap tax avoidance.Penelitian Tandean \& Winnie (2016) menunjukkan hasil bahwa kepemilikan institusional berpengaruh terhadap tax avoidance. Sedangkan dewan komisaris dan kualitas audit tidak berpengaruh terhadap tax avoidance.Penelitian Jamei (2017) menjukkan hasil bahwa kepemilikan institusional tidak berpengaruh terhadap tax avoidance. Penelitian Faizah \& Adhivinna (2017) menunjukkan hasil bahwa kepemilikan institusional tidak berpengaruh terhadap tax avoidance. Penelitian Mappadang et al. (2018) menunjukkan hasil bahwa dewan komisaris dan kepemilikan institusional berpengaruh terhadap tax avoidance. Penelitian Mulyani et al. (2018) menunjukkan hasil bahwa kepemilikan institusional, kualitas audit, dan komite audit berpengaruh terhadap tax avoidance. Penelitian Kalil (2019) menunjukkan hasil bahwa kepemilikan institusional dan komite audit berpengaruh terhadap tax avoidance.

\section{Kerangka Pemikiran}

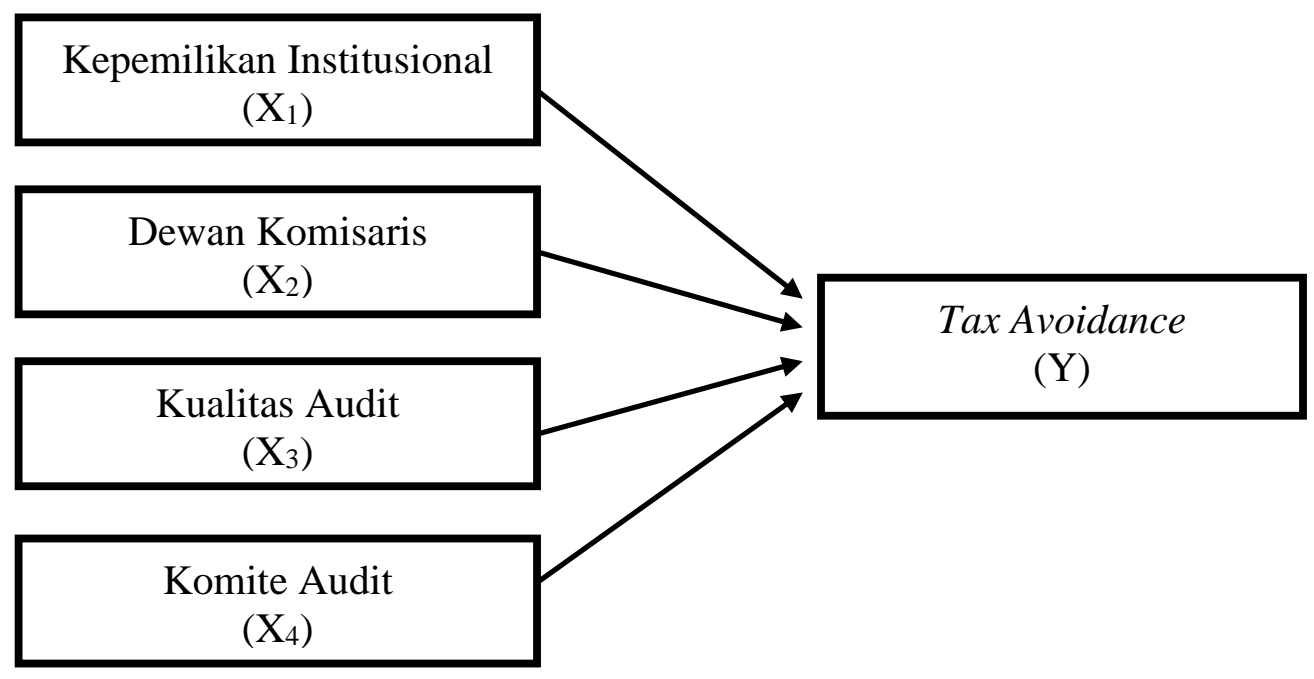

Gambar 1.1 Kerangka Pemikiran

\section{Hipotesis dalam penelitian ini adalah sebagai berikut :}

$\mathrm{H}_{1}$ : Kepemilikan Institusionalberpengaruh terhadap tax avoidance.

$\mathrm{H}_{2}$ : Dewan Komisaris berpengaruh terhadap tax avoidance.

$\mathrm{H}_{3}$ : Kualitas Auditberpengaruh terhadap tax avoidance.

$\mathrm{H}_{4}$ : Kualitas Auditberpengaruh terhadap tax avoidance. 


\section{METODE PENELITIAN}

Penelitian ini merupakan penelitian kuantitatif. Variabel dependennya adalah Tax Avoidance(Y). Sedangkan variabel independennya adalah Kepemilikan Institusional $\left(\mathrm{X}_{1}\right)$, Dewan Komisaris $\left(\mathrm{X}_{2}\right)$, Kualitas Audit $\left(\mathrm{X}_{3}\right)$, danKomite Audit $\left(\mathrm{X}_{4}\right)$. Teknik analisis data menggunakan regresi linier berganda. Sumber data yang digunakanadalah data sekunder sedangkan instrumen data menggunakan dokumentasi. Populasi dalam penelitian ini adalah perusahaan Property dan Real Estate yang terdaftar di BEItahun 2014-2018. Teknik pemilihan sampel menggunakan purposive sampling.

Tabel 1

\section{Hasil Pemilihan Sampel}

\begin{tabular}{llc}
\hline \multicolumn{1}{c}{ Kriteria } & Jumlah \\
\hline 1 & $\begin{array}{l}\text { Perusahaan Sub Sektor Property dan Real Estate yang } \\
\text { terdaftar di Bursa Efek Indonesia Tahun 2014-2018. }\end{array}$ & 48 \\
2 & $\begin{array}{l}\text { Perusahaan Sub Sektor Property dan Real Estate yang } \\
\text { tidak menerbitkan annual report secara berturut-turut }\end{array}$ & $(15)$ \\
& $\begin{array}{l}\text { selama periode 2014-2018. } \\
\text { Perusahaan Sub Sektor Property dan Real Estate yang }\end{array}$ & $(1)$ \\
& $\begin{array}{l}\text { laporan tahunan perusahaan tidak menggunakan mata uang } \\
\text { rupiah. }\end{array}$ & \\
4 & $\begin{array}{l}\text { Perusahaan Sub Sektor Property dan Real Estate yang } \\
\text { tidak memperoleh laba pada tahun 2014-2018. }\end{array}$ & $(7)$ \\
& $\begin{array}{l}\text { Perusahaan Sub Sektor Property dan Real Estate yang } \\
\text { tidak memiliki data lengkap. }\end{array}$ & $(2)$ \\
Jumlah Sampel Perusahaan & $\mathbf{2 3}$ \\
Jumlah Observasi (23 Perusahaan x 5 tahun & $\mathbf{1 1 5}$ \\
Jumlah Data Outlier & $\mathbf{( 3 3 )}$ \\
Jumlah Data Observasi & $\mathbf{8 2}$ \\
\hline
\end{tabular}

Sumber : Lampiran

\section{HASIL DAN PEMBAHASAN}

\section{A. Uji Statistik Deskriptif}

Tabel 2

Uji Statistik Deskriptif

\begin{tabular}{|c|c|c|c|c|c|c|}
\hline & Variabel & $\mathbf{N}$ & Min & Max & Mean & Std. Deviation \\
\hline & Kepemilikan & 82 &, 09 & ,93 &, 6046 & ,20647 \\
\hline & Institusional & & & & & \\
\hline & Dewan Komisaris & 82 & 2,00 & 7,00 & 4,0000 & 1,19670 \\
\hline & Kualitas Audit & 82 &, 00 & 1,00 & ,3780 & ,48788 \\
\hline & Komite Audit & 82 & 2,00 & 3,00 & 2,9512 & ,21673 \\
\hline & Tax Avoidance & 82 &, 06 & ,74 & ,2495 &, 15271 \\
\hline
\end{tabular}


r : Hasil Pengolahan Data Sekunder, 2019

\section{B. Uji Asumsi Klasik}

\section{Uji Normalitas}

Tabel 3

Uji NormalitasOne Sample Kolmogorov -Smirnov Test

\begin{tabular}{cccc}
\hline Variabel & Signifikansi & Standar & Keterangan \\
\hline $\begin{array}{c}\text { Unstandardized } \\
\text { Residual }\end{array}$ & 0,359 & $>0,05$ & $\begin{array}{c}\text { Data variabel } \\
\text { berdistribusi normal }\end{array}$ \\
\hline
\end{tabular}

Sumber : Hasil Pengolahan Data Sekunder, 2019

\section{Uji Multikolinearitas}

Tabel 4

Uji Multikolinieritas

\begin{tabular}{|c|c|c|c|c|c|}
\hline Variabel & Tolerance & Std & VIF & Std & Keterangan \\
\hline $\begin{array}{l}\text { Kepemilikan } \\
\text { Institusional }\end{array}$ & ,715 & $>0,10$ & 1,398 & $<10$ & $\begin{array}{c}\text { Tidak } \\
\text { terjadi } \\
\text { multikolinieritas }\end{array}$ \\
\hline $\begin{array}{l}\text { Dewan } \\
\text { Komisaris }\end{array}$ & ,762 & $>0,10$ & 1,312 & $<10$ & $\begin{array}{c}\text { Tidak } \\
\text { terjadi } \\
\text { multikolinieritas }\end{array}$ \\
\hline Kualitas Audit & ,794 & $>0,10$ & 1,259 & $<10$ & $\begin{array}{c}\text { Tidak } \\
\text { terjadi } \\
\text { multikolinieritas }\end{array}$ \\
\hline Komite Audit & ,965 & $>0,10$ & 1,036 & $<10$ & $\begin{array}{c}\text { Tidak } \\
\text { terjadi } \\
\text { multikolinieritas }\end{array}$ \\
\hline
\end{tabular}

Sumber : Hasil Pengolahan Data Sekunder, 2019

\section{Uji Autokorelasi}

Tabel 5

Uji Autokorelasi Durbin Watson

\begin{tabular}{ccccccc}
\hline Model & DW & $\mathbf{d L}$ & $\mathbf{d U}$ & $\mathbf{4 - d U}$ & $\mathbf{4 - \mathbf { d L }}$ & Keterangan \\
\hline 1 & 1,783 & 1,5406 & 1,7446 & 2,2554 & 2,4594 & $\begin{array}{l}\text { Tidak terjadi } \\
\text { autokorelasi }\end{array}$ \\
\hline
\end{tabular}

Sumber : Hasil Pengolahan Data Sekunder, 2019

Dari hasil yang didapatkan dapat dilihat bahwa nilai DW adalah sebesar 1,783dan dibandingkan dengan batas atas (dU) dan (4-dU), dimana dU sebesar 1,7446 sehingga hasil DW berada diantara (dU) dan (4-Du) $1,7446<1,1783<$ 2,2554 sehingga dapat disimpulkan bahwa tidak terjadi autokorelasi. 


\section{Uji Heteroskedastisitas}

Tabel 6

Uji Heteroskedastisitas

\begin{tabular}{|c|c|c|c|}
\hline Variabel & Sig & Std & Keterangan \\
\hline Kepemilikan Institusional & 0,836 & $>0,05$ & $\begin{array}{c}\text { Tidak terjadi } \\
\text { heteroskedastisitas }\end{array}$ \\
\hline Dewan Komisaris & 0,875 & $>0,05$ & $\begin{array}{c}\text { Tidak terjadi } \\
\text { heteroskedastisitas }\end{array}$ \\
\hline Kualitas Audit & 0,722 & $>0,05$ & $\begin{array}{c}\text { Tidak terjadi } \\
\text { heteroskedastisitas }\end{array}$ \\
\hline Komite Audit & 0,765 & $>0,05$ & $\begin{array}{c}\text { Tidak terjadi } \\
\text { heteroskedastisitas }\end{array}$ \\
\hline
\end{tabular}

Sumber : Hasil Pengolahan Data Sekunder, 2019

\section{Analisis Regresi Linier Berganda}

1. Model Regresi

Tabel 7

Hasil Uji Analisis Regresi Linier Berganda

\begin{tabular}{lc}
\hline \multicolumn{1}{c}{ Variabel } & B \\
\hline Konstanta &, 333 \\
Kepemilikan Institusional &, 030 \\
Dewan Komisaris &,- 045 \\
Kualitas Audit &,- 168 \\
Komite Audit &, 049 \\
\hline
\end{tabular}

Sumber : Hasil Pengolahan Data Sekunder, 2019

Berdasarkan hasil pengujian pada tabel 7 di atas maka diperoleh persamaan regresi linier berganda sebagai berikut :

$Y=0,333+0,030 X_{1}-0,045 X_{2}-0,168 X_{3}+0,049 X_{4}+e$

Nilai Konstanta sebesar 0,333 artinya tax avoidance akan sebesar 0,333 jika variabel kepemilikan institusional, dewan komisaris, kualitas audit, dan komite audit bernilai konstan (0). Koefisien regresi variabel kepemilikan institusional bernilai 0,030, artinya jika variabel kepemilikan institusional naik sebesar satu satuan maka tax avoidanceakan naik sebesar 0,030 dengan catatan variabel independen lainnya bernilai konstan (0). Koefisien regresi variabel dewan komisaris bernilai - 0,045, artinya jika variabel dewan komisaris naik sebesar satu satuan maka tax avoidanceakan turun sebesar 0,045 dengan catatan variabel 
independen lainnya bernilai konstan (0). Koefisien regresi variabel kualitas audit bernilai - 0,168 , artinya jika variabel kualitas audit naik sebesar satu satuan maka tax avoidanceakan turun sebesar 0,168 dengan catatan variabel independen lainnya bernilai konstan (0). Koefisien regresi variabel komite audit sebesar 0,049, artinya jika variabel komite audit naik sebesar satu satuan maka tax avoidanceakan naik sebesar 0,049 dengan catatan variabel independen lainnya bernilai konstan (0).

\section{Uji Kelayakan Model (Uji F)}

\section{Tabel 8}

Uji F

\begin{tabular}{cccccc}
\hline Model & $\mathrm{F}_{\text {hitung }}$ & $\mathrm{F}_{\text {tabel }}$ & Sig & Standar & Keterangan \\
\hline Regression & 7,629 & 2,490 & 0,000 & $<0,05$ & Modellayak \\
\hline
\end{tabular}

Sumber : Hasil Pengolahan Data Sekunder, 2019

Hasil ini menunjukkan bahwa $F_{\text {hitung }}>F_{\text {tabel }} 7,629>2,490$ dan nilai signifikansi $<0,05(0,000<0,05)$, maka dari hasil uji $\mathrm{F}$ ini dapat disimpulkan bahwa model regresi yang digunakan dalam penelitian ini layak, serta seluruh variabel independen berpengaruh secara simultan terhadap variabel dependen.

\section{Uji Hipotesis (Uji T)}

\section{Tabel 9}

\section{Uji Parsial}

\begin{tabular}{lrrrrl}
\hline \multicolumn{1}{c}{ Variabel } & Thitung $_{\text {habel }}$ & $\mathbf{T}_{\text {tabel }}$ & Sig & Std & Keterangan \\
\hline Kepemilikan & 0,351 & 1,991 &, 727 & $<0,05$ & Ditolak \\
Institusional & & & & & \\
Dewan Komisaris & $-3,218$ & $-1,991$ &, 002 & $<0,05$ & Diterima \\
Kualitas Audit & $-4,969$ & $-1,991$ &, 000 & $<0,05$ & Diterima \\
Komite Audit & 0,705 & 1,991 &, 483 & $<0,05$ & Ditolak \\
\hline
\end{tabular}

Sumber : Hasil Pengolahan Data Sekunder, 2019

\section{a. Pengaruh Kepemilikan Institusional terhadap Tax Avoidance.}

Berdasarkan pengujian hipotesis menunjukkan hasil bahwa variabel Kepemilikan Institusional memiliki nilai t hitung < t tabel sebesar 0,351 < 1,991 dengan sig sebesar 0,727>0,05. Dari hasil penelitian ini menunjukkan bahwa variabel Kepemilikan Institusional secara parsial tidak berpengaruh 
terhadap tax avoidancepadaperusahaan Property dan Real Estate yang terdaftar di Bursa Efek Indonesia periode 2014-2018. Hal ini dapat dikarenakan kepemilikan institusional yang bertindak sebagai pihak yang memonitor perusahaan belum tentu mampu memberikan kontrol yang baik terhadap tindakan manajemen atas sikap oportunistiknya dalam melakukan praktik tax avoidance tanpa mengoptimalkan perannya. Menurut penelitian Meiza (2015) menyatakan besar kecilnya konsentrasi kepemilikan institusional akan mempengaruhi kebijakan tindakan meminimalkan beban pajak oleh perusahaan. Penelitian ini sejalan dengan penelitian (Fajar, Zulbahridar, \& Kurnia, 2018)

\section{b. Pengaruh Dewan Komisaris terhadap Tax Avoidance.}

Berdasarkan pengujian hipotesis menunjukkan hasil bahwa variabel Dewan Komisaris memiliki nilai t hitung $<\mathrm{t}$ tabel sebesar $-3,218>-1,991$ dengan sig sebesar 0,002>0,05. Dari hasil penelitian ini menunjukan bahwa variabel Dewan Komisaris secara parsial berpengaruhnegatif terhadap tax avoidancepadaperusahaan Property dan Real Estate yang terdaftar di Bursa Efek Indonesia periode 2014-2018. Hal ini menunjukkan bahwa semakin banyak dewan komisaris maka semakin efektif kinerja mereka dalam melakukan pengawasan dan pengendalian terhadap kinerja direksi atau manajer. Penelitian ini memberikan bukti bahwa semakin banyak jumlah anggota dewan komisarismaka akan semakin rendahtax avoidance. Sebaliknya, semakin rendah jumlah anggota dewan komisarismaka akan semakin tinggi tax avoidance. Penelitian ini sejalan dengan penelitian yang dilakukan oleh Murniawati(2019).

\section{c. Pengaruh Kualitas audit terhadap Tax Avoidance.}

Berdasarkan pengujian hipotesis menunjukkan hasil bahwa variabel Kualitas Audit memiliki nilai t hitung $<\mathrm{t}$ tabel sebesar $-4,969<-1,991$ dengan sig sebesar $0,000<0,05$. Dari hasil penelitian ini menunjukan bahwa variabel Kualitas Audit secara parsial berpengaruh negatif terhadap tax avoidancepadaperusahaan Property dan Real Estate yang terdaftar di Bursa Efek Indonesia periode 2014-2018. Hasil penelitian ini memberikan 
bukti bahwa semakintinggi kualitas auditmaka akan semakin rendahtax avoidance. Sebaliknya, semakin rendah kualitas auditakan semakin tinggi tax avoidance.Penelitian ini sejalan dengan penelitian yang dilakukan oleh penelitian Mulyani et al. (2018)

\section{d. Komite audit tidak berpengaruh terhadap Tax Avoidance.}

Berdasarkan pengujian hipotesis menunjukkan hasil bahwa variabel Komite Audit memiliki nilai t hitung <t tabel sebesar 0,705<1,991 dengan sig sebesar 0,483>0,05. Dari hasil penelitian ini menunjukan bahwa variabel Komite Audit secara parsial tidakberpengaruh terhadap tax avoidancepadaperusahaan Property dan Real Estate yang terdaftar di Bursa Efek Indonesia periode 2014-2018. Hasil dari penelitian ini menunjukan bahwa sedikit atau banyaknya jumlah komite audit yang terdapat dalam suatu perusahaan tidak berpengaruh terhadap penghindaran pajak. Kecenderungan perusahaan dalam melakukan penghindaran pajak bukan dari jumlah banyaknya komite audit melainkan dari kualitas kerja yang dilakukan oleh anggota komite audit itu sendiri, penelitian ini sejalan dengan penelitian yang dilakukan oleh Tandean \& Winnie (2016).

\section{Koefisien Determinasi (Adjusted $\boldsymbol{R}^{2}$ )}

\section{Tabel 10 \\ Uji Koefisien Determinasi (Adjusted $\boldsymbol{R}^{2}$ )}

\begin{tabular}{cc}
\hline AdjustedR Square & Keterangan \\
\hline 0,247 & $\begin{array}{c}\text { Variabel independen berpengaruh sebesar } \\
24,7 \% \text { terhadap variabel dependen }\end{array}$ \\
\hline
\end{tabular}

Sumber : Hasil Pengolahan Data Sekunder, 2019

Nilai Adjusted $R$ Square sebesar 0,247 artinya bahwa persentase sumbangan pengaruh variabel Independen sebesar $24,7 \%$ terhadap variabel dependen, sedangkan $75,3 \%$ dipengaruhi oleh variabel lainnya. 


\section{KESIMPULAN DAN SARAN}

Berdasarkan hasil analisis dan uji hipotesis yang telah dilakukan dalam penelitian ini, maka dapat disimpulkan :

a. Kepemilikan Institusional tidak berpengaruh terhadap tax avoidancepada perusahaan Property dan Real Estate tahun 2014-2018.

b. Dewan Komisaris berpengaruh negatif terhadap tax avoidancepada perusahaan Property dan Real Estate tahun 2014-2018.

c. Kualitas Audit berpengaruh negatif terhadap tax avoidancepada perusahaan Property dan Real Estate tahun 2014-2018.

d. Komite Audittidak berpengaruh terhadap tax avoidancepada perusahaan Property dan Real Estate tahun 2014-2018.

e. Kepemilikan Institusional, Dewan Komisaris, Kualitas Audit, dan Komite Audit berpengaruh secara simultan (bersama-sama) terhadap tax avoidance.

Adapun saran yang dapat penulis berikan dari penelitian ini yaitu :

a. Disarankan tidak hanya menggunakan perusahaan Property dan Real Estate sebagai populasi penelitian, tetapi juga menggunakan perusahaan lain yang terdaftar di Bursa Efek Indonesia.

b. Diharapkan untuk penelitian selanjutnya dapat menambahkan variabel-variabel yang mempengaruhi tax avoidance, seperti variabel dewan komisaris independen, dewan direksi, kepemilikan manajerial, dan lain-lain.Karena variabel independen dalam penelitian ini hanya mampu menjelaskan variasi variabel dependen sebesar 24,7\%. Berdasarkan presentase tersebut menunjukkan bahwa masih banyak variabel-variabel lain yang dapat mempengaruhi tax avoidance.

\section{DAFTAR PUSTAKA}

Alviyani, K., Surya, R. A. S., \& Rofika, R. (2016). Pengaruh Corporate Governance, Karakter Eksekutif, Ukuran Perusahaan, Dan Leverage Terhadap Penghindaran Pajak (Tax Avoidance)(Studi Pada Perusahaan Pertanian Dan Pertambangan Yang Terdaftar Di BEI Tahun 2011-2014). Jurnal Online Mahasiswa Fakultas Ekonomi Universitas Riau, 3(1), 2540-2554.

Annisa, N. A., \& Kurniasih, L. (2012). Pengaruh Corporate Governance Terhadap Tax Avoidance. Jurnal Akuntansi dan Auditing , 95 - 189. 
Bukhori, I., \& Raharja. (2012). Pengaruh good corporate governance dan ukuran perusahaan terhadap kinerja perusahaan (studi empiris pada perusahaan yang terdaftar di BEI 2010). Fakultas Ekonomika dan Bisnis.

Darmawan, \& Abdi, D. (2017). Pengembangan Metode Peningkatan Kualitas Laporan Keuangan pada PT. Pelabuhan Indonesia IV Berbasis Good Corporate Governance di Kota Parepare. Jurnal Ekonomi Pembangunan STIE Muhamadiyah Palopo, 109-117.

Darmawan, I. G. H., \& Sukartha, I. M. (2014). Pengaruh Penerapan Corporate Governance, Leverage, Roa, dan Ukuran Perusahaan pada Penghindaran Pajak. EJurnal Akuntansi, 143-161.

Faizah, S. N., \& Adhivinna, V. V. (2017). Pengaruh Return On Asset, Leverage. Kepemilikan Institusional dan Ukuran Perusahaan terhadap Tax Avoidance. Jurnal Akuntansi, 5(2), 136-145.

Fajar, M., Zulbahridar, \& Kurnia, P. (2018). Pengaruh Profitabilitas, leverage, corporate governance terhadap tax avoidance (Studi empiris pada perusahaan manufaktur yang terdaftar di Bursa Efek Indonesia periode 2012-2014). JOM FEB, 1-15.

Guna, W. I., \& Herawaty, A. (2010). Pengaruh mekanisme good corporate governance, independensi auditor, kualitas audit dan faktor lainnya terhadap manajemen laba. Jurnal bisnis dan akuntansi, 12(1), 53-68.

Hanum, H. R., \& Zulaikha, Z. (2013). Pengaruh Karakteristik Corporate Governance Terhadap Effective Tax Rate (Studi Empiris pada BUMN yang Terdaftar di BEI 2009-2011). Diponegoro Journal of Accounting, 201-210.

Haruman, T. (2008). Pengaruh Struktur Kepemilikan terhadap Keputusan Pendanaan (Perspektif Agency Theory) Survey Pada Perusahaan Manufaktur di PT. Bursa Efek Indonesia.

Jamei, R. (2017). Tax Avoidance and Corporate Governance Mechanisms: Evidence from Tehran Stock Exchange. International Journal of Economics and Financial Issues, 7(4), 638-644.

Jensen, M. C., \& Meckling, W. H. (1976). Theory of the firm: Managerial behavior, agency costs and ownership structure. Journal of financial economics, 305-360.

Kalil, N. (2019). The effects of corporate governance mechanism on tax avoidance behavior of a firm in the transportation and logistic sector in Brazil. International Journal of Advanced Economics, 1(2), 55-60.

Kementrian Keuangan. (2018). APBN 2018. Diambil 25 Desember 2019, dari Kementerian Keuangan Republik Indonesia website: https://www.kemenkeu.go.id/apbn2018 
Komite Nasional Kebijakan Governance (KNKG). (2006). Pedoman Umum Good Corporate Governance Indonesia. Diambil dari https://ecgi.global/sites/default/files//codes/documents/indonesia_cg_2006_id.pdf

Lanis, R., \& Richardson, G. (2012). Corporate social responsibility and tax aggressiveness: An empirical analysis. Journal of Accounting and Public Policy, 31(1), 86-108.

Mappadang, A., Widyastuti, T., \& Wijaya, A. M. (2018). The Effect of Corporate Governance Mechanism on Tax Avoidance: Evidence from Manufacturing Industries Listed in the Indonesian Stock Exchange. The International Journal of Social Sciences and Humanities Invention, 5(10), 5003-5007.

Marfirah, D., \& Syam, F. (2016). Pengaruh Corporate Governance dan Leverage Terhadap Tax Avoidance Pada Perusahaan Manufaktur Yang Terdaftar di Bursa Efek Indonesia (BEI) Tahun 2011-2015. Jurnal Ilmiah Mahasiswa Ekonomi Akuntansi, 1(2), 91-102.

Meiza, Randi. 2015. Pengaruh Karakteristik Good Corporate Governance dan Defereed Tax Expense Terhadap Tax Avoidance. Jurnal Akuntansi Universitas Padang, 3 (1).

Mulyani, S., Wijayanti, A., \& Masitoh, E. (2018). Pengaruh Corporate Governance terhadap Tax Avoidance (Perusahaan Pertambangan yang terdaftar di BEI). Jurnal Riset Akuntansi Dan Bisnis Airlangga, 3(1).

Murniawati, E. (2019). Pengaruh Corporate Governance terhadap Penghindaran Pajak pada Perusahaan Manufaktur yang terdaftar di Bursa Efek Indonesia Tahun 2014-2017.

Pohan, H. T. (2014). Analisis pengaruh kepemilikan institusi, rasio tobin q, akrual pilihan, tarif efektif pajak, dan biaya pajak ditunda terhadap penghindaran pajak pada perusahaan publik. Jurnal Informasi, Perpajakan, Akuntansi Dan Keuangan Publik, 4(2), 113-135.

Puspita, S. R., \& Harto, P. (2014). Pengaruh Tata Kelola Perusahaan terhadap Penghindaran Pajak. Diponegoro Journal of Accounting, 3(2), 1077-1089.

Sari, G. M. (2014). Pengaruh Corporate Governance, Ukuran Perusahaan, Kompensasi Rugi Fiskal dan Struktur Kepemilikan terhadap Tax Avoidance (Studi Empiris Pada Perusahaan Manufaktur yang Terdaftar di BEI tahun 2008-2012). Jurnal Akuntansi.

Susiana, A. H. (2007). Analisis pengaruh independensi, mekanisme corporate governance, dan kualitas audit terhadap integritas laporan keuangan. Simposium Nasional Akuntansi X.

Tandean, V. A., \& Winnie, W. (2016). The Effect of Good Corporate Governance on 
Tax Avoidance: An Empirical Study on Manufacturing Companies Listed in IDX period 2010-2013. Asian Journal of Accounting Research, 1(1).

Winata, F. (2014). Pengaruh Corporate Governance terhadap Tax Avoidance pada Perusahaan yang Terdaftar di Bursa Efek Indonesia Tahun 2013. Tax \& Accounting Review, 4(1), 162. 